\title{
Proteasome Inhibitor Lactacystin Induces Cholinergic Degeneration
}

\author{
Hai-Yan Zhou, Yu-Yan Tan, Zhi-Quan Wang, Gang Wang, Guo-Qiang Lu, \\ Sheng-Di Chen
}

\begin{abstract}
Objective: Ubiquitin proteasome system dysfunction is believed to play an important role in the development of Parkinson's disease (PD), and almost all studies till now have mainly focused on the susceptibility of dopaminergic neurons to proteasome inhibition. However, in fact, there are many other types of neurons such as cholinergic ones involved in PD. In our present study, we attempt to figure out what effect the failure of ubiquitin proteasome function would execute on cholinergic cells in culture. Methods: We treated cholinergic cells in culture with various doses of lactacystin. Then MTT assay was used to evaluate the cellular viability and the AnnexinV-PI method was used to detect apoptosis. Both cellular soluble and insoluble polyubiquitinated proteins were detected by western blot. Furthermore, the mitochondrial membrane potential was analyzed using JC-1 and the intracellular production of reactive oxygen species (ROS) was determined using the fluorescent probe CM-H2DCFDA. Results: We found that low doses of lactacystin were enough to induce significant apoptotic cell death, disturb the mitochondrial membrane potential, and cause oxidative stress. We also found that the amounts of polyubiquitinated proteins dramatically increased with high doses, although the loss of cells did not increase accordingly. Conclusions: Our results suggest that cholinergic cells are sensitive to ubiquitin proteasome system dysfunction, which exerts its toxic effect by causing mitochondrial dysfunction and subsequent oxidative stress, not through polyubiquitinated proteins accumulation.
\end{abstract}

RÉSUMÉ: La lactacystine, un inhibiteur du protéasome, induit une dégénérescence cholinergique. Objectif : La dysfonction du système protéasome-ubiquitine jouerait un rôle important dans la genèse de la maladie de Parkinson (MP) et presque toutes les études ont ciblé la susceptibilité des neurones dopaminergiques à l'inhibition du protéasome. Cependant, il y a plusieurs autres types de neurones tels les neurones cholinergiques qui son impliqués dans la MP. Dans cette étude nous avons cherché à comprendre quelles sont les conséquences d'une dysfonction du système protéasomeubiquitine sur des cellules cholinergiques en culture. Méthodes : Nous avons traité des cellules cholinergiques en culture au moyen de différentes doses de lactacystine. Nous avons ensuite utilisé le test MTT pour évaluer la viabilité cellulaire et la méthode AnnexinV-PI pour détecter l'apoptose. Les protéines cellulaires polyubiquitinées solubles et insolubles ont été détectées par buvardage de Western. De plus, le potentiel membranaire mitochondrial a été analysé par mesure du flux de JC-1 et la production intracellulaire de radicaux libres a été déterminée au moyen de la sonde fluorescente CMH2DCFDA. Résultats : Nous avons constaté que de faibles doses de lactacystine étaient suffisantes pour induire une mort cellulaire significative par apoptose, perturber le potentiel membranaire mitochondrial et causer un stress oxydatif. Nous avons également constaté que la quantité de protéines polyubiquitinées augmentait dramatiquement lorsque de hautes doses étaient utilisées, même si la perte cellulaire n'augmentait pas proportionnellement. Conclusion : Selon nos résultats, les cellules cholinergiques seraient sensibles à la dysfonction du système protéasome-ubiquitine qui produit son effet toxique en causant une dysfonction mitochondriale et un stress oxydatif subséquent et non par accumulation de protéines polyubiquitinées.

Can. J. Neurol. Sci. 2010; 37: 229-234

The failure of ubiquitin proteasome (UP) function is widely believed to participate in the development of Parkinson's disease (PD) $)^{1-3}$. Recent studies have shown that most causative genes of familial PD are associated with ubiquitin proteasome system, including $\alpha$-synuclein ${ }^{4}$, parkin ${ }^{5}$, ubiquitin carboxy-terminal hydrolase L1 (UCH-L1) ${ }^{6}$ and DJ-1 ${ }^{7}$. Above all, evidence shows that proteasome inhibition has been found in the substantia nigra pars compacta $(\mathrm{SNpc})$ of sporadic $\mathrm{PD}^{8-10}$, which accounts for 95 percent of all PD cases. All of these have triggered big interest in exploring the role of UP dysfunction in the pathogenesis of PD. Recently several studies have revealed that proteasome inhibitors could produce excellent PD animal models ${ }^{11-13}$, although they could hardly be replicated by other research groups $^{14-18}$.

From the Department of Neurology \& Institute of Neurology (HYZ, YYT, GW, GQL, SDC), Ruijin Hospital affiliated to Shanghai Jiaotong University School of Medicine; Institute of Health Science (ZQW, SDC), Shanghai Institutes of Biological Sciences, Chinese Academy of Science \& Shanghai Jiaotong University School of Medicine, Shanghai, China.

Received August 18, 2009. Final Revisions Submitted October 15, 2009. Correspondence to: Sheng-Di Chen, Department of Neurology \& Institute of Neurology, Ruijin Hospital affiliated to Shanghai Jiaotong University School of Medicine, Shanghai 20025, China. 
Almost all studies up to now have mainly focused on the susceptibility of dopaminergic neurons to proteasome inhibition, although in fact, there are many other types of neurons involved in PD, such as cholinergic neurons ${ }^{19-21}$. During the neurodegenerative process of PD, some cholinergic neurons are damaged as severely as dopaminergic neurons ${ }^{20,21}$. Therefore, cholinergic neurons may be as sensitive to the failure of UP function as dopaminergic neurons. In the present study, we attempt to figure out what effect the failure of UP function would exert on cholinergic cells in culture.

\section{Materials ANd Methods}

Cell culture. Mouse cholinergic SN56 cells were kindly provided by Proffessor Jianzhi Wang (Department of Pathophysiology, School of Basic Medical Sciences, Tongji Medical College, Huazhong University of Science and Technology, China). The cell lines were cultured at $37^{\circ} \mathrm{C}$ in $5 \%$ $\mathrm{CO}_{2}$ in Dulbecco's modified Eagle's medium supplemented with $10 \%$ inactive fetal bovine serum, $100 \mathrm{U} / \mathrm{ml}$ penicillin and $100 \mu \mathrm{g} / \mathrm{ml}$ streptomycin (Invitrogen, Carlsbad, CA).

Cell viability analysis. Cells were seeded in 96-well plates and cultured for $48 \mathrm{~h}$. Then they were treated with various concentrations $(1 \mu \mathrm{M}, 5 \mu \mathrm{M}, 10 \mu \mathrm{M}, 20 \mu \mathrm{M})$ of lactacystin (Lact) (Sigma, St Louis, MO) for 24h. After incubation, the cell viability was assessed by quantitative colorimetric assay with 3 (4, 5-Dimethyl-2-thiazolyl)-2, 5-diphenyl-2H-tetrazolium bromide (MTT, Sigma) according to the manufacturer's protocol.

Detection of apoptosis. The cells were treated as described in the MTT assay. After 24 hours of treatment, the supernatants were discarded, and the cells were washed with phosphatebuffered saline (PBS) and harvested after digestion with nonEDTA trypsin. Then the cells were stained with $2 \mu$ Annexin V and $1 \mu \mathrm{l}$ PI reagent (Santa Cruz, California, USA) for $15 \mathrm{~min}$ in the dark at room temperature. Fluorescence densities were measured with a FACS Calibur flow cytometer.

Measurement of mitochondrial membrane potential. The mitochondrial membrane potential was analyzed using JC-1, a lipophilic fluorescence probe (MitoProbe, Molecular Probes, Eugene, OR). The cells were seeded in 6-well plates and treated for 24 hours with various concentrations of Lact. The medium was then replaced with medium containing $\mathrm{JC}-1$ at a final concentration of $10 \mu \mathrm{g} / \mathrm{ml}$, followed by incubation at $37^{\circ} \mathrm{C}$ under $5 \% \mathrm{CO}_{2}$ for ten minutes. The trypsinized cells were harvested, washed with cold PBS and analyzed using a FACS Calibur flow cytometer.

Measurement of reactive oxygen species (ROS). The intracellular production of ROS was determined using the fluorescent probe CM-H2DCFDA (Molecular Probes). CMH2DCFDA is a nonfluorescent reagent that forms fluorescent esters after reacting with ROS inside cells. The procedure was like JC-1 staining, except that the final concentration of CMH2DCFDA was $1 \mu \mathrm{M}$ and the incubation time in the dark at room temperature was ten minutes.

Western blot analysis. Cells were treated for 24 hour with various concentrations of Lact. Total cell lysates were prepared with radioimmunoprecipitation (RIPA) buffer (Sigma) containing 1 x complete protease inhibitors (Roche, Germany), according to the manufacturer's protocol. Insoluble material was recovered by centrifugation at $12,000 \mathrm{x}$ g for 20 minutes. Pellets were resuspended in $2 \%$ sodium dodecylsulfate (SDS) buffer (50
$\mathrm{mM}$ Tris-HCl, $\mathrm{pH}$ 7.6, $2 \%$ SDS). Protein lysates were quantified using the bicinchoninic acid protein assay (bicinchoninic acid assay was used to quantify protein lysates.) (Pierce, Rockford, IL). Samples containing equal amounts of total proteins were separated on $8 \%$ SDS-polyacrylamide gels and analyzed by western blotting with antibodies against polyubiquitinated conjugates (clone FK1, 1:1000, BioMol, Plymouth Meeting, $\mathrm{PA}$ ), followed by the corresponding secondary antibody. Electrochemiluminescence detection was performed according to the manufacturer's protocol (Pierce). The membranes were

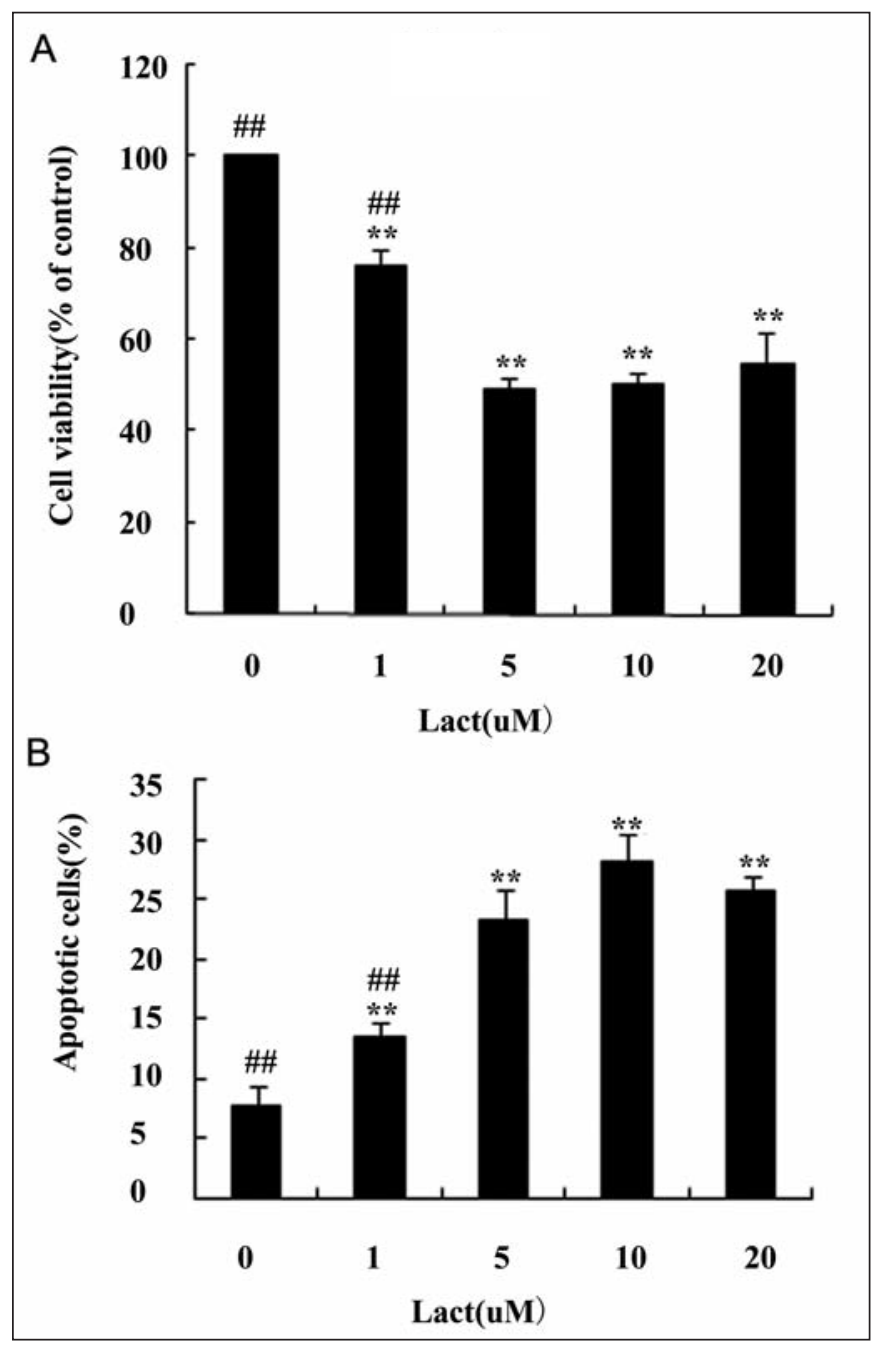

Figure 1: Lact-induced cellular toxicity. A) Neurotoxicity of Lact on cell viability. SN56 cells were treated with $1 \mu M, 5 \mu M, 10 \mu M, 20 \mu M$ Lact for $24 \mathrm{~h}$, and cell viability was measured. The data are represented as mean \pm S.D. of four independent experiments. The percentage of surviving cells relative to the number in the untreated group is represented. B) Lactinduced apoptosis. Cells were treated as in the MTT assay, and apoptosis was analyzed using fluorescent activated cell sorting. The data are represented as mean $\pm S . D$. of three independent experiments. $* * p<0.01$ vs. control group; \#\#p<0.01 vs. Lact $(5 \mu M)$-treated group. 
washed with stripping buffer (Pierce) and incubated with a $\beta$ actin monoclonal antibody (1:3000, Sigma) to confirm equal loading.

Statistical analysis. All experiments were performed at least in triplicate. The statistical package SPSS11.5 was used for all analyses. All values were expressed as mean \pm SD. One-way analysis of variance (ANOVA), followed by post-hoc LSD multiple comparison test was used to determine the significance of differences. A value of $\mathrm{P}<0.05$ was considered statistically significant.

\section{RESULTS}

\section{Proteasomal inhibition induces apoptotic cell death}

As we expected, cholinergic SN56 cells showed sensitivity to the toxicity of Lact, the specific proteasome inhibitor, and a dose of $1 \mu \mathrm{M}$ was enough to induce significant cell death. However, with the concentration increasing, the survival rate of SN56 cells did not decrease in a dose-dependent manner. Lact at a dose of $5 \mu \mathrm{M}$ reached the peak of cytotoxicity, and higher doses did not further aggravate the situation (Figure 1A). With the AnnexinVPI double staining, we found that cholinergic cells exposed to Lact experienced apoptosis, and confirmed that Lact at a dose of $5 \mu \mathrm{M}$ reached the plateau neurotoxicity (Figure 1B).

\section{Proteasomal inhibition induces mitochondrial-dependent apoptosis}

In order to determine whether Lact-induced apoptosis of SN56 cells could be ascribed to an alteration of mitochondrial activity, mitochondrial membrane potential was measured by ratiometric probe JC-1. Then we found that Lact at a dose of $1 \mu \mathrm{M}$ significantly damaged the membrane potential of mitochondria, and again $5 \mu \mathrm{M}$ Lact reached the damage peak, with the similar percentage showed by AnnexinV-PI double staining. However, in contrast to AnnexinV-PI double staining, with higher doses than $5 \mu \mathrm{M}$, the function of mitochondria was restored and at a dose of $20 \mu \mathrm{M}$, a significant portion of cells escaped the mitochondrial damage compared with $5 \mu \mathrm{M}$ Lact (Figure 2).

\section{Proteasomal inhibition induces oxidative stress}

To determine whether proteasomal inhibition could induce oxidative stress, we used CM-H2DCFDA to detect cellular reactive oxygen species (ROS). Similar to the tendency of mitochondrial membrane potential, Lact at a dose of $5 \mu \mathrm{M}$ induced strongest oxidative stress, while with the concentration increasing, oxidative stress attenuated (Figure 3).

\section{Proteasomal inhibition induces polyubiquitinated proteins production}

To explore the relationship between proteasomal inhibition and the accumulation of polyubiquitinated proteins in cholinergic cells, we used Western blot to detect both soluble and insoluble intracellular polyubiquitinated proteins. Then we were surprised to find that low doses including $5 \mu \mathrm{M}$ did not lead to significant accumulation of polyubiquitinate proteins, although they induced significant cell death. On the contrary, at higher doses of $10 \mu \mathrm{M}$ and $20 \mu \mathrm{M}$, both soluble and insoluble
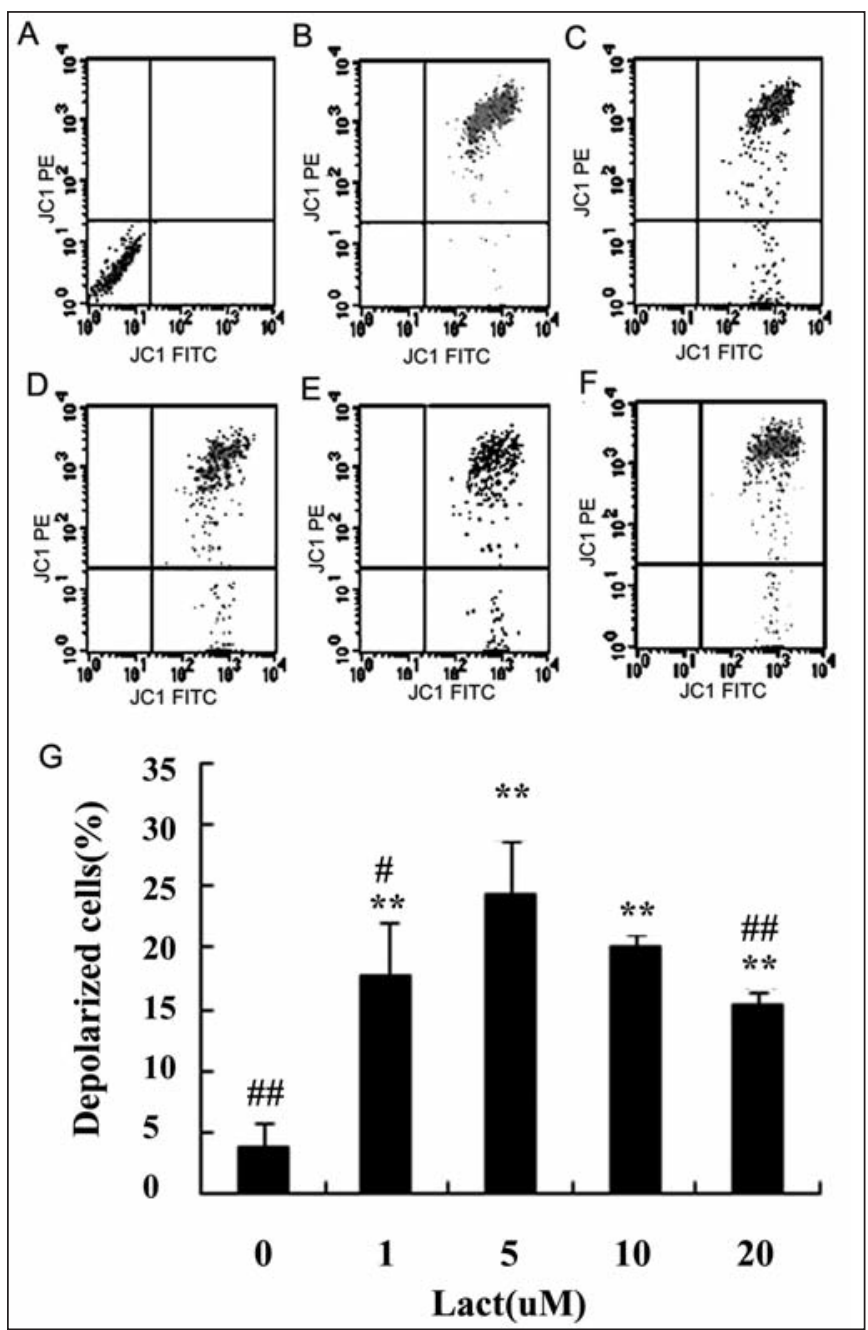

Figure 2: Effect of Lact on mitochondrial membrane potential. (A)-(F) Flow cytometry data with JC-1. (A) Negative control. (B) Control group. (C) Lact $(1 \mu M)$-treated group. (D) Lact $(5 \mu M)$-treated group. (E) Lact $(10 \mu M)$-treated group. $(F)$ Lact $(20 \mu M)$-treated group. $(G)$ Percentage of depolarized cells in SN56 cells. Data are represented as mean $\pm S . D$. of three independent experiments. ${ }^{*} p<0.01$ vs. control group. $\# p<0.05$, $\# \# p<0.01$ vs. Lact $(5 \mu M)$-treated group .

intracellular polyubiquitinated proteins markedly increased, although the percentage of cell death did not further increase (Figure 4).

\section{DISCUSSION}

Loss of dopaminergic neurons in the substantia nigra pars compacta and the appearance of Lewy bodies in the remaining neurons are the two pathologic hallmarks of PD. Therefore, numerous studies have been devoted to disclosing the myth of the dopaminergic neurons' death. In fact, many types of neuronal cells besides dopaminergic neurons are involved in $\mathrm{PD}^{19,20}$. For 
instance, during the neurodegenerative process of PD, some cholinergic nuclei are damaged as severely as and even earlier than dopaminergic neurons ${ }^{19-21}$. Unfortunately few studies have been done to determine the mechanism of cholinergic neuron degeneration in $\mathrm{PD}^{12}$. Since proteasome impairment has been believed to play an important role in the development of $\mathrm{PD}^{1-3}$, we are intrigued to figure out what effect it would exert on the cholinergic neurons. In our present study, it was demonstrated that proteasomal impairment by the proteasomal inhibitor Lact exerts cytotoxic effects on cultured cholinergic cells by causing mitochondrial dysfunction and subsequent oxidative stress, but not through polyubiquitinated protein accumulation.

As shown here, cholinergic cells are sensitive to the proteasomal impairment and low doses of Lact are enough to induce cytotoxicity. The percentage of apoptotic cells reaches $16 \%$ at a dose of $1 \mu \mathrm{M}$ and $23 \%$ at a dose of $5 \mu \mathrm{M}$, which is similar to that of undifferentiated $\mathrm{PC} 12$ cells $^{11}$ and primary rat midbrain dopaminergic neurons ${ }^{22}$ respectively. Although it is not a direct comparison, it may suggest at least that cholinergic cells are vulnerable to the proteasomal inhibition. Another more interesting phenomenon is that doses higher than $5 \mu \mathrm{M}$ do not induce more cell death, somewhat may attenuate the situation implied by restoration of mitochondrial function and less production of ROS. Similar phenomena have recently been reported by Suh and his colleagues ${ }^{23}$. They found that murine cortical cell cultures exposed to $0.1 \mu \mathrm{M}$ MG132 underwent widespread neuronal apoptosis, but administration of $1-10 \mu \mathrm{M}$ MG132 resulted in reduced neuronal apoptosis. They suggested that these paradoxical effects of proteasome inhibitors depended on the degree of reduced proteasome activity; that is, partial blockade of proteasome activity led to activation of a mitochondria-dependent apoptotic signaling cascade, while complete blockade interfered with progression of apoptosis.

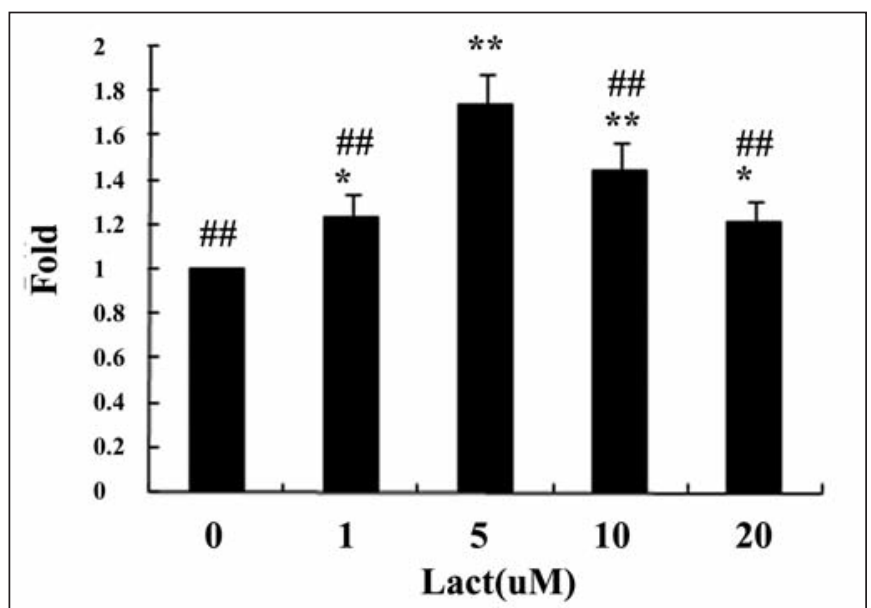

Figure 3: Effect of Lact on ROS. SN56 cells were treated with $1 \mu M$, $5 \mu M, 10 \mu M, 20 \mu M$ Lact and the cellular ROS was measured using CM$H 2 D C F D A$. The data are represented as mean $\pm S D$ of three independent experiments. ${ }^{*} p<0.05, * * p<0.01$ vs. control group, \#\#p<0.01vs. Lact (5 $\mathrm{MM})$-treated group.
Would that be the case for cholinergic cells? Further investigation has to be done to figure it out and the underlying mechanism may be useful for preventing the degeneration of dopaminergic neurons.

The mechanism by which proteasome inhibitors induce apoptosis has been thoroughly researched. Mitochondrial dysfunction has been demonstrated by many researches. In cultured cortical neurons and sympathetic neurons, proteasome inhibitors have been shown to induce cell death by a mitochondria-dependent apoptotic mechanism ${ }^{23-25}$. In neuroblastoma SH-SY5Y cells, mitochondria homeostasis and mitochondria turnover are altered by proteosome inhibitors ${ }^{26}$. They can also induce the apoptosis of glioma cell lines by releasing cytochrome $\mathrm{c}$ and activating multiple caspases ${ }^{27,28}$. Our data indicate that Lact definitely disturbed the mitochondrial membrane potential in cultured murine cholinergic SN56 cells, and $5 \mu \mathrm{M}$ Lact reached the damage peak.

Another hypothesis is that proteasomal dysfunction causes or augments oxidative and nitrative stress ${ }^{29}$. The study by Kikuchi et $\mathrm{al}^{30}$ has shown that proteasome inhibitor could augment oxidative stress by producing more ROS, and some researchers have reported that proteasomal inhibition hypersensitized the dopaminergic cells to oxidative injury ${ }^{31,32}$. However, Yamamoto et $\mathrm{al}^{33}$ have recently suggested that proteasome inhibition protected cells from oxidative stress by inducing glutathione synthesis. Our study demonstrates that Lact induced oxidative stress in SN56 cells by producing ROS. With the doses increasing, the extent of oxidative stress attenuated rather than aggravated, suggesting that proteasome inhibition might have dual effects on oxidative stress.

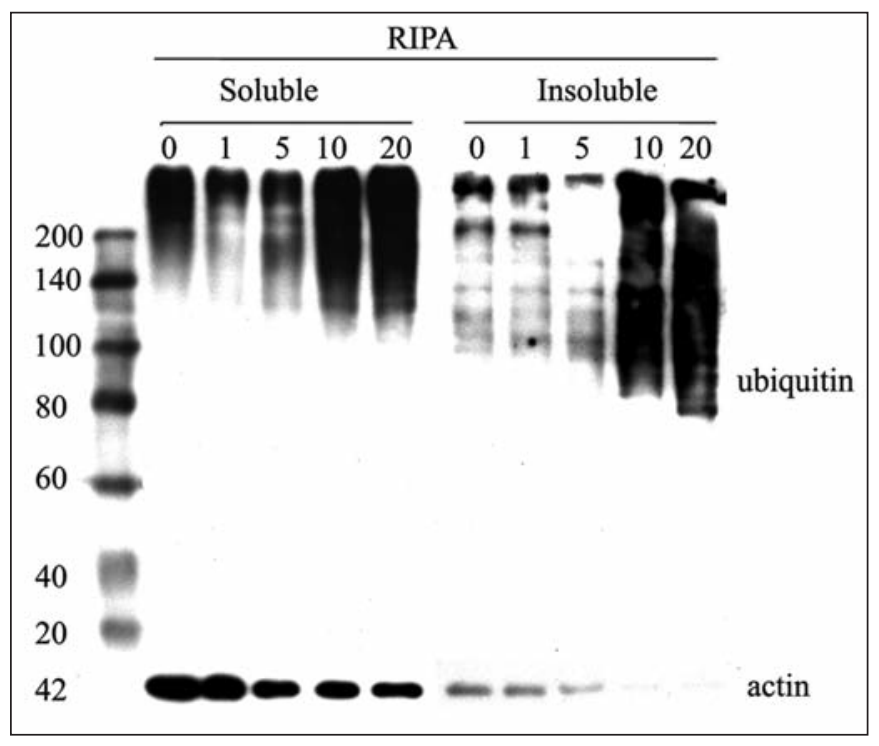

Figure 4: Effect of Lact on the levels of polyubiquitinated proteins. SN56 cells were treated with $1 \mu M, 5 \mu M, 10 \mu M, 20 \mu M$ Lact for $24 h$, and cellular RIPA-soluble and RIPA-insoluble polyubiquitinated proteins were analyzed by western blotting with an anti-polyubiquitinated conjugate antibody or an anti-actin antibody (loading control). The experiment was repeated thrice independently. 
Whether intraneuronal inclusion bodies are toxic or non-toxic or even protective to neurons has been intensely debated ${ }^{34,35}$. Previously, it was believed that either ubiquitinated inclusions or Lewy bodies are toxic to neurons, because they occur with the loss of neurons ${ }^{34,35}$. However, evidence shows that Lewy bodies in substantia nigra neurons are absent in most patients with autosomal recessive juvenile parkinsonism ${ }^{36,37}$. Some authors have argued that the formation of inclusion bodies and the toxicity of proteasome inhibitors are probably two parallel pathways $^{38,39}$. Obviously, in our study, proteasomal inhibition does not exert its toxin through accumulating the polyubiquitinated proteins; contrarily, it may somewhat suggest that the process of polyubiquitinated protein accumulating is beneficial to cholinergic cells, because with the doses higher than $5 \mu \mathrm{M}$, the death rate does not increase further, whereas the mitochondrial function has restored and oxidative stress has attenuated slightly but significantly.

\section{Conclusions}

To summarize, lactacystin induced mitochondrial dysfunction and apoptotic cell death in cholinergic cells. It also produced oxidative stress and the accumulation of polyubiquitinated proteins, but the latter does not appear to be responsible for cell degeneration.

\section{ACKNOWLEDGEMENTS}

The authors thank Professor Jian-Zhi Wang for the gift of SN56 cell lines. This work was funded by the National Program of Basic Research (2006cb500706, 2010CB945200) of China, the National Natural Science Fund (30872729, 30971031), Shanghai Key Project of Basic Science Research (07DJ14005, 09DZ1950400), Key Discipline Program of Shanghai Municipality (S30202) and Program for Outstanding Medical Academic Leader (LJ 06003).

\section{REFERENCES}

1. Dawson TM, Dawson VL. Molecular pathways of neurodegeneration in Parkinson's disease. Science. 2003;302 (5646):819-22.

2. McNaught KS, Olanow CW. Proteolytic stress: a unifying concept for the etiopathogenesis of Parkinson's disease. Ann Neurol. 2003;53 Suppl 3:S73-84.

3. Moore DJ, West AB, Dawson VL, Dawson TM. Molecular pathophysiology of Parkinson's disease. Annu Rev Neurosci. 2005;28:57-87.

4. Polymeropoulos MH, Lavedan C, Leroy E, Ide SE, Dehejia A, Dutra A, et al. Mutation in the alpha-synuclein gene identified in families with Parkinson's disease. Science. 1997;276(5321): 2045-7.

5. Kitada T, Asakawa S, Hattori N, Matsumine H, Yamamura Y, Minoshima S, et al. Mutations in the parkin gene cause autosomal recessive juvenile parkinsonism. Nature. 1998;392 (6676):605-8.

6. Leroy E, Boyer R, Auburger G, Leube B, Ulm G, Mezey E, et al. The ubiquitin pathway in Parkinson's disease. Nature. 1998;395 (6701):451-2.

7. Bonifati V, Rizzu P, van Baren MJ, Schaap O, Breedveld GJ, Krieger E, et al. Mutations in the DJ-1 gene associated with autosomal recessive early-onset parkinsonism. Science. 2003; 299(5604):256-9.

8. McNaught KS, Jenner P. Proteasomal function is impaired in substantia nigra in Parkinson's disease. Neurosci Lett. 2001;297 (3):191-4.
9. McNaught KS, Belizaire R, Jenner P, Olanow CW, Isacson O. Selective loss of $20 \mathrm{~S}$ proteasome alpha-subunits in the substantia nigra pars compacta in Parkinson's disease. Neurosci Lett. 2002; 326(3):155-8.

10. McNaught KS, Belizaire R, Isacson O, Jenner P, Olanow CW. Altered proteasomal function in sporadic Parkinson's disease. Exp Neurol. 2003;179(1):38-46.

11. Fornai F, Lenzi P, Gesi M, Ferrucci M, Lazzeri G, Busceti CL, et al. Fine structure and biochemical mechanisms underlying nigrostriatal inclusions and cell death after proteasome inhibition. J Neurosci. 2003;23(26):8955-66.

12. McNaught KS, Perl DP, Brownell AL, Olanow CW. Systemic exposure to proteasome inhibitors causes a progressive model of Parkinson's disease. Ann Neurol. 2004;56(1):149-62.

13. Schapira AH, Cleeter MW, Muddle JR, Workman JM, Cooper JM, King RH. Proteasomal inhibition causes loss of nigral tyrosine hydroxylase neurons. Ann Neurol. 2006;60(2):253-5.

14. Mathur BN, Neely MD, Dyllick-Brenzinger M, Tandon A, Deutch AY. Systemic administration of a proteasome inhibitor does not cause nigrostriatal dopamine degeneration. Brain Res. 2007; 1168:83-9.

15. Landau AM, Kouassi E, Siegrist-Johnstone R, Desbarats J. Proteasome inhibitor model of Parkinson's disease in mice is confounded by neurotoxicity of the ethanol vehicle. Mov Disord. 2007;22(3):403-7.

16. Kordower JH, Kanaan NM, Chu Y, Suresh Babu R, Stansell J 3rd, Terpstra BT, et al. Failure of proteasome inhibitor administration to provide a model of Parkinson's disease in rats and monkeys. Ann Neurol. 2006;60(2):264-8

17. Manning-Boğ AB, Reaney SH, Chou VP, Johnston LC, McCormack AL, Johnston J, et al. Lack of nigrostriatal pathology in a rat model of proteasome inhibition. Ann Neurol. 2006;(2):256-60.

18. Hawlitschka A, Haas SJ, Schmitt O, Weiss DG, Wree A. Effects of systemic PSI administration on catecholaminergic cells in the brain,adrenal medulla and carotid body in Wistar rats. Brain Res. 2007; 1173:137-44.

19. Braak H, Del Tredici K, Rub U, de Vos RA, Jansen Steur EN, Braak E. Staging of brain pathology related to sporadic Parkinson's disease. Neurobiol Aging. 2003;24(2):197-211

20. Ahlskog JE. Challenging conventional wisdom: the etiologic role of dopamine oxidative stress in Parkinson's disease. Mov Disord. 2005;20(3):271-82.

21. Zarow C, Lyness SA, Mortimer JA, Chui HC. Neuronal loss is greater in the locus coeruleus than nucleus basalis and substantia nigra in Alzheimer and Parkinson diseases. Arch Neurol. 2003; 60(3):337-41.

22. Rideout HJ, Lang-Rollin IC, Savalle M, Stefanis L. Dopaminergic neurons in rat ventral midbrain cultures undergo selective apoptosis and form inclusions, but do not up-regulate iHSP70, following proteasomal inhibition. J Neurochem. 2005;93(5): 1304-13.

23. Suh J, Lee YA, Gwag BJ. Induction and attenuation of neuronal apoptosis by proteasome inhibitors in murine cortical cell cultures. J Neurochem. 2005;95(3):684-94.

24. Lang-Rollin I, Vekrellis K, Wang Q, Rideout HJ, Stefanis L. Application of proteasomal inhibitors to mouse sympathetic neurons activates the intrinsic apoptotic pathway. J Neurochem. 2004;90(6): 1511-20.

25. Qiu JH, Asai A, Chi S, Saito N, Hamada H, Kirino T. Proteasome inhibitors induce cytochrome c-caspase-3-like proteasemediated apoptosis in cultured cortical neurons. J Neurosci. 2000;20(1):259-65.

26. Sullivan PG, Dragicevic NB, Deng JH, Bai Y, Dimayuga E, Ding Q, et al. Proteasome inhibition alters neural mitochondrial homeostasis and mitochondria turnover. J Biol Chem. 2004;279 (20):20699-707.

27. Wagenknecht B, Hermisson M, Groskurth P, Liston P, Krammer $\mathrm{PH}$, Weller M. Proteasome inhibitor-induced apoptosis of glioma cells involves the processing of multiple caspases and cytochrome c release. J Neurochem. 2000;75(6):2288-97. 
28. Goldbaum O, Vollmer G, Richter-Landsberg C. Proteasome inhibition by MG-132 induces apoptotic cell death and mitochondrial dysfunction in cultured rat brain oligodendrocytes but not in astrocytes. Glia. 2006;53(8):891-901.

29. Halliwell B. Hypothesis: proteasomal dysfunction: a primary event in neurodegeneration that leads to nitrative and oxidative stress and subsequent cell death. Ann N Y Acad Sci. 2002;962:182-94.

30. Kikuchi S, Shinpo K, Tsuji S, Takeuchi M, Yamagishi S, Makita Z, et al. Effect of proteasome inhibitor on cultured mesencephalic dopaminergic neurons. Brain Res. 2003;964(2):228-36.

31. Mytilineou C, McNaught KS, Shashidharan P, Yabut J, Baptiste RJ, Parnandi A, et al. Inhibition of proteasome activity sensitizes dopamine neurons to protein alterations and oxidative stress. J Neural Transm. 2004;111(10-11):1237-51.

32. Lev N, Melamed E, Offen D. Proteasomal inhibition hypersensitizes differentiated neuroblastoma cells to oxidative damage. Neurosci Lett. 2006;399(1-2):27-32.

33. Yamamoto N, Sawada H, Izumi Y, Kume T, Katsuki H, Shimohama $\mathrm{S}$, et al. Proteasome inhibition induces glutathione synthesis and protects cells from oxidative stress: relevance to Parkinson disease. J Biol Chem. 2007;282(7):4364-72.

34. Hung CC, Davison EJ, Robinson PA, Ardley HC. The aggravating role of the ubiquitin-proteasome system in neurodegenerative disease. Biochem Soc Trans. 2006;34(Pt 5):743-5.

35. Ardley HC, Hung CC, Robinson PA. The aggravating role of the ubiquitin-proteasome system in neurodegeneration. FEBS Lett. 2005;579(3):571-6.
36. Shimura H, Hattori N, Kubo S, Yoshikawa M, Kitada T, Matsumine $\mathrm{H}$, et al. Immumohistochemical and subcellular localization of parkin protein: absence of protein in autosomal recessive juvenile parkinsonism patients. Ann Neurol. 1999;45(5):668-72.

37. Schlossmacher MG, Frosch MP, Gai WP, Medina M, Sharma N, Forno L, et al. Parkin localizes to the Lewy bodies of Parkinson disease and dementia with Lewy bodies. Am J Pathol. 2002; 160(5):1655-67.

38. Rideout HJ, Wang Q, Park DS, Stefanis L. Cyclin-dependent kinase activity is required for apoptotic death but not inclusion formation in cortical neurons after proteasomal inhibition. $J$ Neurosci. 2003;23(4):1237-45.

39. Dietrich P, Rideout HJ, Wang Q, Stefanis L. Lack of p53 delays apoptosis, but increases ubiquitinated inclusions, in proteasomal inhibitor-treated cultured cortical neurons. Mol Cell Neurosci. $2003 ; 24(2): 430-41$. 